\title{
Factors Influencing Utilization of Ecosystem Research Findings for Sustainable Management of Lake Naivasha Basin "A Case Study of Hell's Gate Location"
}

\author{
Onyango G.O ${ }^{1}$ Prof. Wegulo F. N. ${ }^{2}$ \\ ${ }^{l}$ (Department of Environment, Egerton University, Kenya) \\ ${ }^{2}$ (Department of Geography, Egerton University)
}

\begin{abstract}
Lake Naivasha is one of the fresh water lakes in the Kenyan Rift Valley. The population within the Lake basin has experienced rapid growth, which has placed enormous strain on the ecosystems within/around it. Critical is over abstraction of underground water by the various flower growing farms, and pollution arising from disposal of both the untreated sewerage and chemicals used in the flower farms. All these effects have potential to adversely affect the already fragile ecosystem, and the general population. Several research activities have already been conducted, with others underway, to capture and document the ecosystem health status within the Lake Basin. In spite of these efforts, ecosystem health degradation is continuing at an alarming rate. Clearly a gap exists between researches conducted on one hand and utilization of the findings for sustainable development on the other hand. The study therefore sought to contribute towards sustainable management of resources in the Lake Naivasha Basin through encouraging appropriate access and utilization of ecosystem health research findings information by the various stakeholders. Specifically the objective was to determine factors influencing utilization of ecosystem health research findings. The study employed a social survey approach. Questionnaires, interview schedules and focus group discussions were used to collect the data. A sample of 304 was arrived by using sample calculator using sample frame of the households of primary stakeholders (flower farm workers, pastoralists, fishing community), who were subjected to pre-tested questionnaires. Data collected were analyzed by SPSS and content analysis. Results from the analysis show that in spite of many research studies already conducted the research findings has not been able to reach the various stakeholders to utilize the information due to lack of accessibility, language used is technical, level of education is low.
\end{abstract}

Keywords: Utilization, Research findings, Sustainable management

\section{Introduction}

Lake Naivasha is a fresh water lake located within the Kenyan section of the Great Rift Valley. The lake derives its name from Naiposha, a Maasai word meaning "rough water" in reference to sudden storms which commonly occur in the area. The lake has a surface area of $139 \mathrm{~km}^{2}$, and is surrounded by a swamp which covers an area of $64 \mathrm{~km}^{2}$. It is situated at an altitude of 1884 meter (6180ft) above sea level. The lake has an average depth of 6 meters (20ft) with the Crescent Island as the deepest end, at a maximum depth of 30 meters (100ft) (Francesca et al., 2011) The Lake provides a habitat to a variety of wildlife, with over 400 different species of birds that include; water fowls, fowls, penguins, flamingos, falcons, eagles, hawks, cranes, doves, parrots, cuckoos, owls, kingfishers, woodpeckers, mouse birds and many others (Francis, 2010). A sizeable population of hippos also exists within the lake. Two smaller Lakes are found within the vicinity of Lake Naivasha, namely Oloiden and Sonachi. The latter lake shore is known for its population of European immigrants and settlers.

Lake Naivasha area plays an important role in national development. It is one of the major contributors of Kenya's export of approximately 134,000 tonnes of cut flower, fresh fruits and vegetables (HCDA, 2007). In 2006 , the proportion for cut flower increased by $40 \%$ compared to fruits and vegetables. At that time 49,000 tonnes of cut flower valued at US\$112 million were exported (Kenya Flower Council, 2006).

Since Kenya's independence in 1963, Lake Naivasha basin has undergone rapid land use transformations characterized by commercial ranching, and small-scale agricultural activities. In the last two decades, the area has become an expansive commercial flower-growing zone, largely by foreign companies. This has increased demand for the scarce ecosystem resources and services, especially water and land. The results have been significant water abstraction from both the Lake and underground sources by the floriculture industry, a major ecosystem health problem.

Accelerated water abstraction through direct and indirect methods poses immediate and long-terms risks to the ecosystem and the existence of the Lake. The demand on water for flower growing is compounded by the needs of the fast growing population. The likelihood of increased ecosystem health degradation is certain 
unless mitigation measures are put in place. What is not immediately clear is whether or not the water users such as flower growing companies are aware of the ecosystem consequences of their actions. Or could it be that they lack essential research based information on the basis of which they could make more informed decisions on management of the basin's resources?

Other harmful practices in the basin include rampant discharge of raw sewage into the Lake, resulting in eutrophication and high demand on available oxygen in the Lake (Mireri, 2005). The consequences of such practice are disastrous for the ecosystem health. A related problem is rampant use of pesticides by flower farms and chemical fertilizers among small scale farmers in the upper catchment area of the Aberdares. It is alleged that some flower farmers are using unacceptable chemicals such as organo-chlorine pesticides and some of these pesticides have been detected in Lake Naivasha (Gitahi et al., 2002). Through biomagnifications, such chemicals could affect bird species at the top of the food chain.

The quantity of data and research on Lake Naivasha and its drainage is overwhelming (Robert et al., 2006). The number of researches done to generate knowledge is 182 (Personal communication Charlie Trick). The key thematic areas which have been researched on are aquatic plants, parasites of fish, different species of fish, water budget, invertebrates, human activities, pollutants in the Lake Naivasha and climate change effect on Lake Naivasha, just to mention a few. Out of the 182 researches done, of interest were; 21 researches covered pollution of the Lake Naivasha, 28 researches covered macro invertebrates/nutrients/breeding/diet, 32 researches covered different species of fish/distribution/weight-length/breeding/diet, 10 researches covered impact of human activities on Lake Naivasha, 8 covered climate change impact on Lake Naivasha, 15 researches covered different species of birds/breeding/feeding and 3 researches covered water budget. These researches are important to people living around Lake Naivasha basin depending on their socioeconomic activities.

Despite all these researches, ecosystem health degradation is still a threat to Lake Naivasha basin. The major challenge might be accessibility since most of the findings are published in international journals not accessible to resource users. The other problem was lack of resource centre where various researches can be stored for easy access by resource users.

\subsection{Statement of the Problem}

Lake Naivasha is an important ecosystem health because it supports a variety of socio-economic activities. As a result of these activities, the population in the area has been increasing rapidly, and has posed a number of challenges to sustainable use of the ecosystem due to over abstraction of water, loss of biodiversity and pollution of the Lake. Review of literature suggests that several empirical studies have so far been conducted and related research findings made known to the researchers but not the resource users. However, it is apparent that the study area continues to experience ecosystem health related problems due to the non utilization of research findings by the resources users. This paradoxical situation raised a fundamental question as to what might be the reason for the mismatch between available ecosystem health research findings and continuing environmental degradation. It was against the recognition of this gap that this study sought to determine factors influencing utilization of ecosystem health research findings by various stakeholders towards sustainable management in Lake Naivasha Basin.

\section{Literature Review}

With the current ecosystem health challenges facing Lake Naivasha Basin, there is a need to determine ecosystem health research information needs based on the current and existing policies in order to come up with ways in which the various ecosystem health research information can be compiled, disseminated and utilized. According to (Michael et al., 2007) factors influencing the utilization of research findings by all stakeholders include access to information, relevance of the research, use of the research perceived as a time consuming process, trust in the research, authority of those who present their views, competency in research methods, and priority of research in policy process and accountability.

(Closset al., 1994) suggested that utilizing research findings was a highly complex task, requiring a positive attitude towards research. (McGuire, 1990) states that the issue of utilizing research findings in practice was more than simply viewing difficulties of using it, as the failure of individuals to respond to new knowledge, or to innovations also counts. In their study, (Goode et al., 1992), revealed that the organization aspect on research management and communication process contributed to research findings' utilization. Thus, utilization of research findings should not be seen as a separate entity which is performed independently of other duties (Roger, 1994). The issue spans the planning phase of research to implementation and actual utilization, including possible implications. Successful application of research findings, therefore, depends upon the interest and commitment of both researcher and user (stakeholder) and cannot be achieved in isolation (Bircumshaw, 1990). The research has established the challenges which affect the utilization of research findings by the stakeholders concern and the possible way to improve the utilization of the information. 
According to research done by (Bond, 2002), a number of policy and profession-led initiatives have moved therapy toward an evident-based culture. Accessing information, particularly research-based findings, is fundamental to the concept of evidence-based practice. Little is known about the extent to which therapists are searching actively for research information, or what they perceive as barriers to accessing research information or implementing research into practice. A mixed method design was used to gather quantitative $(\mathrm{n}=127)$ and qualitative $(n=77)$ data from a population of Occupational, Physiotherapy and Speech and Language therapist employed in rural Community Trusts. The result indicated that only a small proportion of therapy professional in the study adopted a proactive strategy for identifying, retrieving and utilizing research information. Individual, organizational and cultural issues were identified that were perceived to be barrier to the process of accessing and interpreting research findings. Individuals were judged to have different degree of research receptivity. This concept incorporates dimension of self-efficacy with respect and personal impressions of research that combine to encourage or undermine an individual's engagement with research and its products. In conclusion, for better research receptivity, the approach was to increase allocation of resources, provision of educational activity and dissemination of research information that accommodates the research attitudes and skills of individual therapy professionals.

Veeramah (2007) assessed the impact of research education on the attitudes toward research and use of research findings in a sample of graduate nurses and midwifery. His research examined how nurse and midwifery teachers could work collaboratively with clinical staff to enhance their use of research evidence to inform their practice. The main barriers to research utilization and strategies that could facilitate the use of research findings in nursing and midwifery were also explored.

The project was carried out in three phases and aspects of theory of diffusion of innovation and theory of planned behaviour were used as the theoretical framework to inform data collection. For the first phase, a cross-sectional survey using a self-completed postal questionnaire was sent to 340 graduates. A response rate of $56 \%$ was obtained. A large number stated that following graduation, their search and critical appraisal skills had improved, expressed positive attitude towards research and reported using research findings in practice. The second phase explored further the extent of research utilization. Semi-structured interviews were conducted with 10 respondents from a range of specialties. All participants claimed that they used research findings to a large extent and provided examples to support their answers. The third phase, using a structured questionnaire, explored strategies that nurse and midwifery teachers could use to help nurses and midwives to improve their use of research findings. A total of 40 teachers and 62 clinical managers took part. The result was effective strategies were identified including enabling clinical staff to access and critique research papers; run research workshops on site; set up journal club or research interest groups and undertake joint research projects.

\section{Methodology}

The study was conducted in Hell's Gate Location, which is located in Rift Valley Province of Kenya (Figure 1). The population in the area surrounding the lake has rapidly grown from 7000 in 1969 to about 300,000 by 2007 (Food and Water Watch, 2008). It is estimated that the population will be close to one million by 2025 , in consonance with sub-Saharan estimated urban population growth rate of $6.9 \%$ per annum as compared to $3.1 \%$ of the total population of the region (Ayenew et al., 2007). Such growth rate is likely to have serious challenges to sustainable use of Lake Naivasha Basin.

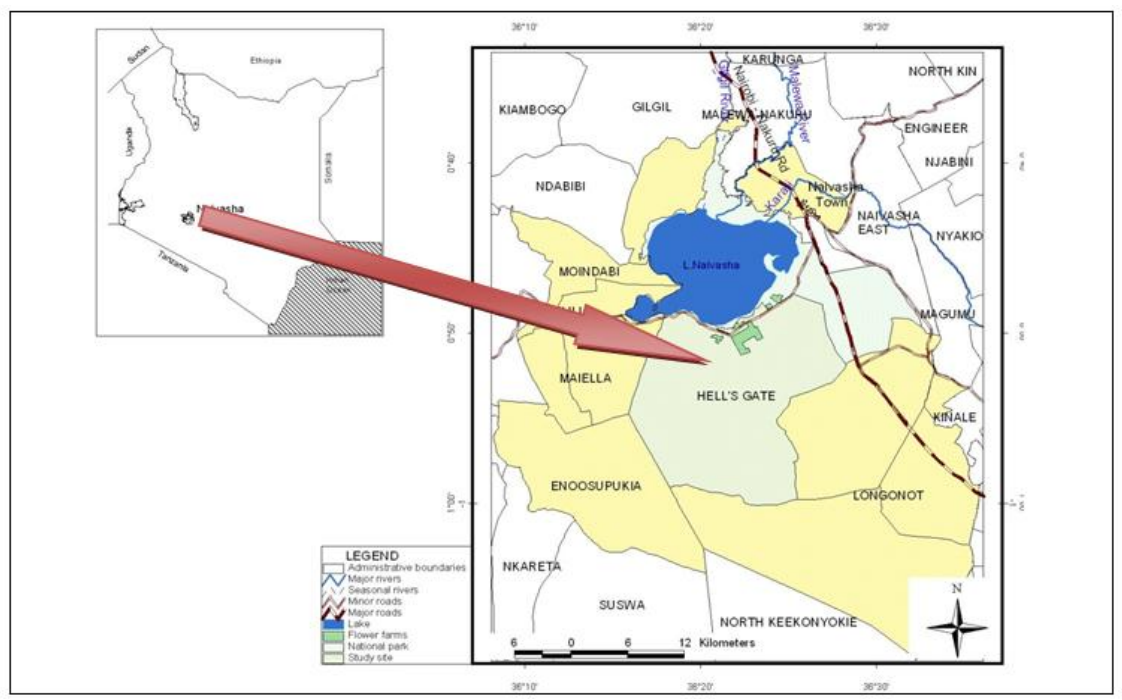

Figure 1: Map of Kenya and Naivasha Basin showing the Study Area (Source Cartographer Egerton University) 
This study employed a social survey research design based on qualitative and quantitative approaches to collect the relevant data from the study areas (Hell's Gate Location). The study targeted individual farmers, pastoralists, flower firm workers housed and not housed within Flower farms company sites, fish monger and business people. The sampling frame included a list of pastoralist, indigenous farmers, and flower firm workers obtained from Hell's Gate Location Chief's Office. A total of 304 respondents were targeted by the study. Questionnaires, interview schedules and focus group discussions were used to collect the data. Both quantitative and qualitative data analysis techniques were used to analyze the data. The quantitative data were analyzed using descriptive statistics while thematic analysis technique was used to analyze the qualitative data collected through focus group discussions and interviews.

\section{Findings of the Study}

This objective focused on determining factors which influence utilization of ecosystem health research information in the LNB. The LNB has experienced growth in recent years as a result of population influx. This has led to increased economic activities such as flower farming, fishing and tourism. The sum total of this growth has been environmental degradation. This is in spite of a wide range of research conducted on various dimensions of resources within the basin (Robert et al., 2006). This study therefore sought to determine the factors contributing to continued environmental degradation even with seemly adequate ecosystem health research information generated on this aspect.

In response to the question as to whether the respondents were aware of researches activities going on within Lake Naivasha Basin, majority of the respondents indicated that they were not aware. Leading in lack of awareness were the pastoralists $86.7 \%$, followed closely with self employed $79.1 \%$, farmers $75.7 \%$ and employed $63.4 \%$. Only the fishermen $54.5 \%$ indicated that they were aware of the research being carried out around the lake. This was attributed to the fact that many fishermen interacted with the researchers as they carry out their activities in the Lake (Figure 2).

Lack of awareness among the pastoralists can be attributed to the migratory life styles of this group precluding their chances of meeting or interacting with researchers. Lack of education or low level of education may also have contributed to lack of awareness by member of the pastoral community. The lack of awareness by the self employed was probably due to being tied at their place of business and therefore hardly getting time to interact or meet researchers. The same situation is probably applicable to the employed respondents most of whom are tied up at their places of work hence do not get the opportunity to meet or interact with researchers. As for farmers, lack of awareness can be attributed to the fact that farming is undertaken on the outskirts of the town where interaction with researchers is minimized, since most research activities are concentrated around or inside the Lake Naivasha.

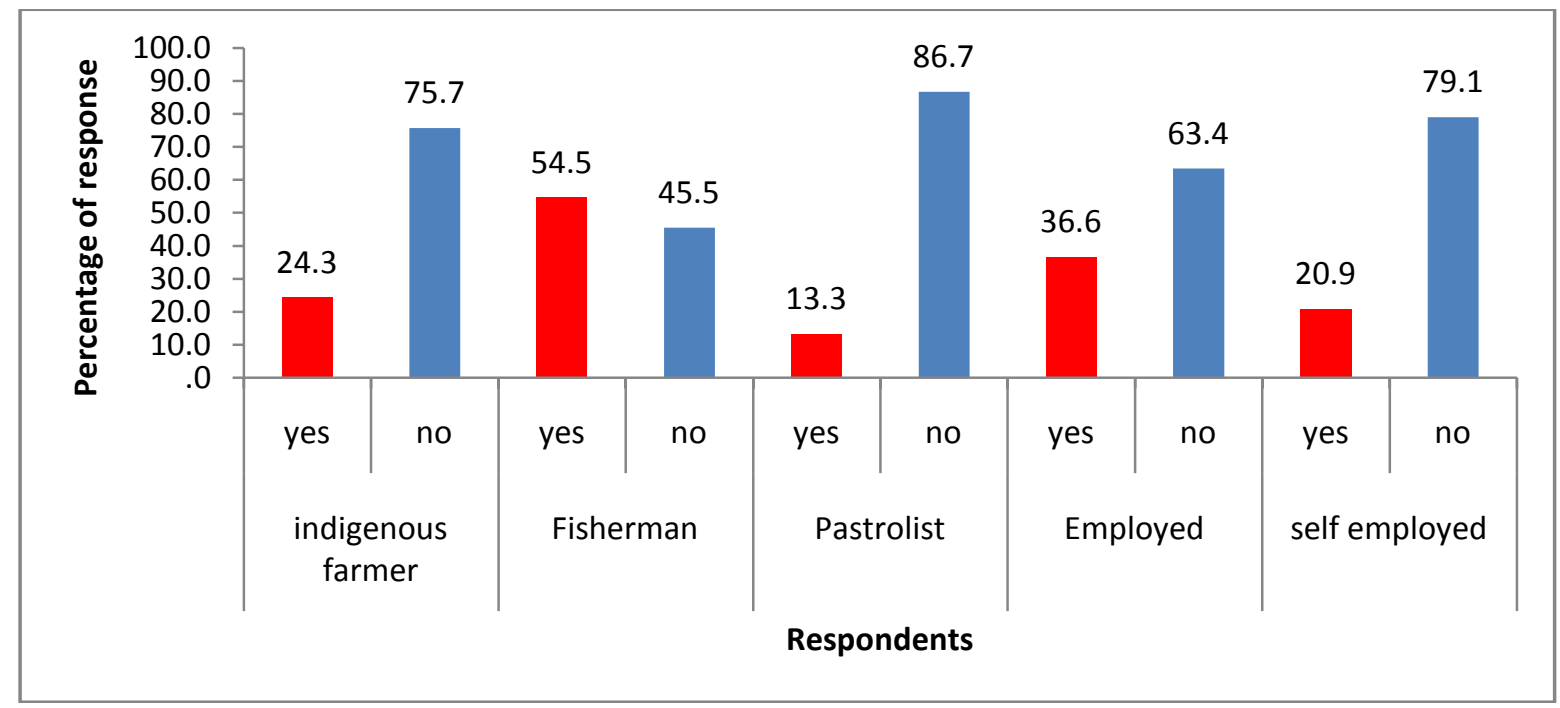

Key: Yes= Aware of research activities, No= Not aware of research activities

Figure 2: Awareness of Research activities by Respondents

In responses to the question as to how much knowledge the respondents had on the effect of chemicals on the environment and human health, the study found that indigenous farmers had above average knowledge as indicated by $35 \%$ of the respondents. It was also found that only $5 \%$ had average knowledge on the effect of chemicals on environment and human health. This may be attributed to the type of farming which involves only minimal use of chemicals. As for the fishing community, the study found that $59 \%$ of the respondents had above 
average knowledge of the effects of chemicals on the environment and human health. This can be attributed to the Lake Naivasha surrounded by many flower farms, which fishermen might have witnessed discharging chemicals waste into it which affect the quality of water and fish. Fishermen might also be interacting/mingling with many researchers with whom they may be sharing with information hence the high level of awareness. Regarding the knowledge of the pastoralists, the study found that $35 \%$ of the respondents had most knowledge, followed by some knowledge $27 \%$, and above average knowledge at $24 \%$. This may probably be attributed to pastoralists keeping large numbers of livestock and they use the environment to get pasture and water to feed their livestock. Pastoralists have also seen cattle die due to poisoning, grazing land reduced and polluted. This is a probable explanation for the knowledge the group has on effect of chemicals. Among the employed respondents, the study found that $35 \%$ of the respondents had above average knowledge and $32 \%$ had some knowledge on the effect of chemicals on the environment and health. This can be attributed to their working environment. It is possible that some come into contact with chemicals directly or indirectly at their work place. From the response of the self employed, $36 \%$ had above average knowledge, followed by least knowledge at $22 \%$, average knowledge and some knowledge was less than $15 \%$ respectively. This may be attributed to self employed socioeconomic activities which do not involve the use of chemicals (Figure 3 ).

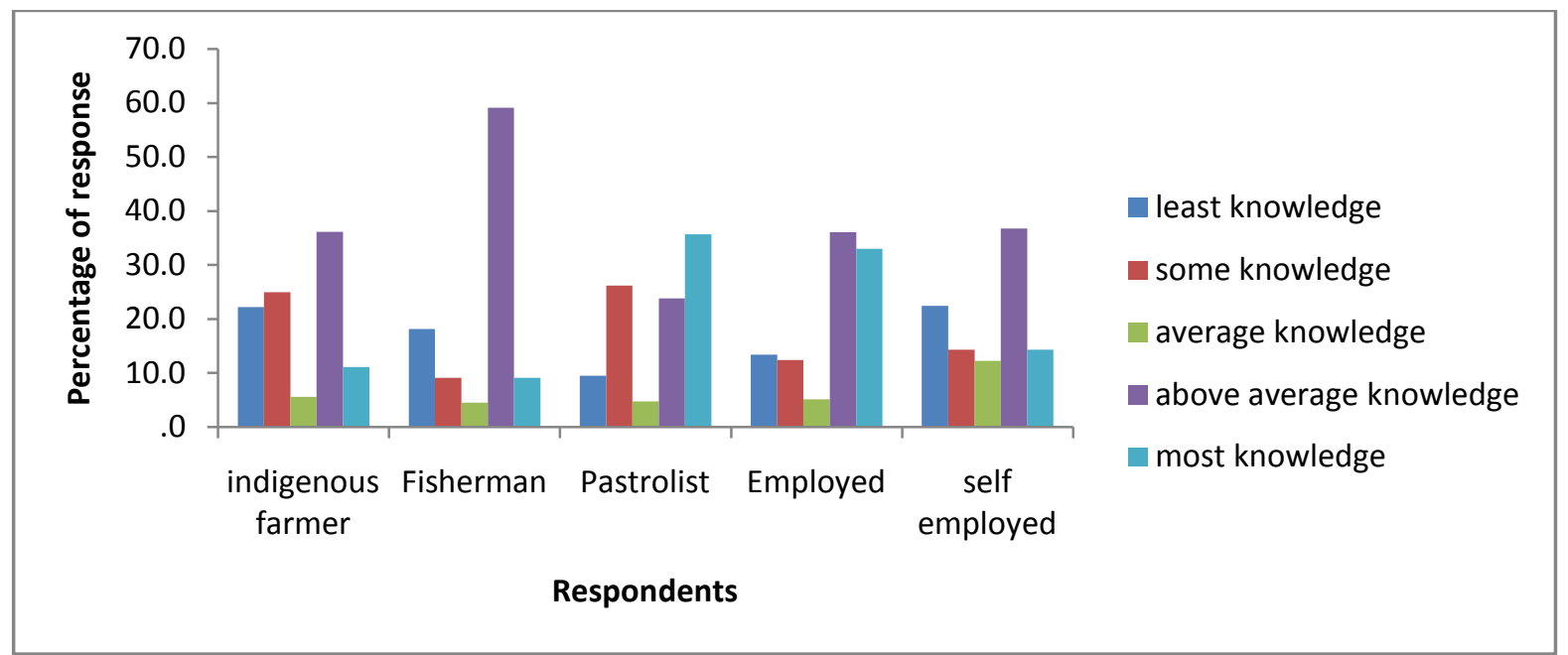

Figure 3: Knowledge of Respondents on Effect of Chemicals on Environment and Health

The sample respondents were asked about the usefulness of ecosystem health research findings. For "very useful" leading was pastoralist $25 \%$, followed by employed $24.2 \%$, fishermen $13 \%$, farmers $10.8 \%$ and finally self employed $10.3 \%$. For "useful" the responses were fishermen $39.1 \%$, farmers $35.1 \%$, pastoralist $22.5 \%$, self employed $10.3 \%$, and finally Employed 8.8\%. "Above average usefulness" of research findings leading was self employed $48.7 \%$, followed by employed $41.8 \%$, fishermen $34.8 \%$, pastoralist $32.5 \%$ and farmers $21.6 \%$. These results elaborate probably the fact that ecosystem health research findings are useful to respondent in one way or the other and this had strong link with their socioeconomic activities (Figure 4).

For the self employed $48.7 \%$ the research findings were above average useful to them, this can probably be attributed to the fact that they interact with employed, pastoralists, fishermen and farmers, they have seen or witnessed how chemicals affect their health in one way or the other. This probably explains why the research finding is "above averagely" useful to them to try to understand some of the challenges. For the employed $41.8 \%$ research findings are "above averagely" useful to them due to the fact that most of them are employed in flower farms and they have probably also seen or witnessed how people are affected by chemical and may want to know why that is the case.

This concurs with Mzee Joseph Wafula Wangia whose Son (24 years of age) was employed with one of the flower farms as a sprayer. He joined the farm three years ago very health, for the time he has worked there his health has deteriorated very much, he suspect that he was affected by chemical in the flower farms. His son has been tested for malaria, HIV, tuberculosis and all results are negative. But the company says his son suffers from malaria, but Mzee Wangia ask how comes he is vomiting blood? He is not convinced. He thinks more research need to be done to find connection between chemicals used in flower farms and human health and this can help many people (personal communication). 
With regard to the pastoralists $32.5 \%$ the research finding is above averagely useful to them probably due to the fact that they use environment there to get pasture and water for their livestock. They have also seen some of their livestock die as a result of chemical poisoning and that explains why they are probably seeking answers through research findings.

This is concurring with Mzee William Ochodo (pastoralist), the chemicals used by flower farms to spray crops are finding their way into the Lake and these pollute it. When livestock drink the water they get affected by chemicals, some become infertile and other die (personal communication).

Just like the pastoralists, $34.8 \%$ of the fishermen the research findings are "above averagely" useful to them and this probably attributed to the fact that they have seen fish die in the Lake, income from fishing going down due to low catch. They have seen/interacted more with researchers carrying out research in the Lake and they have learned more from them. This probably explains the curiosity to seek for answers through research to explain the deaths of the fish and low catch. For the farmers $21.6 \%$ research findings are "above averagely" useful to them, this was probably attributed to the fact that most farming is done on the outskirt of Naivasha and hence less interaction with effects of chemicals or minimum use of chemicals. That explains low usefulness of research findings to farmers.

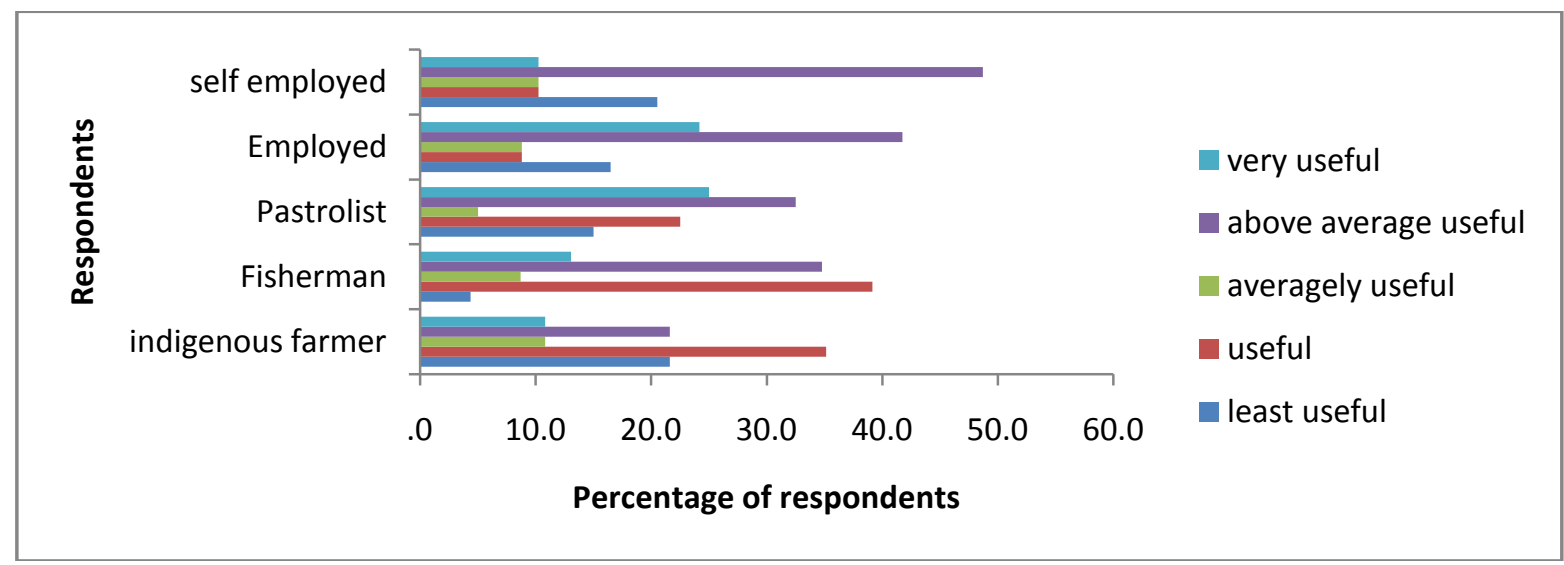

Figure 4: Usefulness of Research Information

On probing further the kind of researches going on within the study area, the respondents were asked to mention the kinds of researches going on within the study area which they know. The study established that, farmers mentioned environmental issues $38 \%$, followed by chemicals in Lake $25 \%$, pollution $12 \%$ and human health $12 \%$ respectively. The farmers were probably more concern with their immediate environment where they do most of the farming activities and a few were concern with pollution of the Lake and human health. Fishermen mentioned water $66 \%$, followed by pollution of Lake $16 \%$, chemicals in Lake $8 \%$ and environmental issues $8 \%$ respectively. This probably explains that fishermen were more concern about state of water and pollution of the lake by flower farms since they have witnessed fish dying, low catch of fish and low income from fishing in the Lake.

The study further found that pastoralists were aware of researches going on as follows; environmental issues $40 \%$, water $20 \%$, human health $20 \%$, chemical in Lake $20 \%$. The pastoralist being migratory people with their livestock they are very close to nature. They use pasture from the surrounding environment for their livestock, use water from the Lake to water their livestock and are concern about their health since they drink the water directly without treatment. They see themselves as being vulnerable and hence the concern for their livestock and health. Employed respondents mentioned the researches which they were aware of going on within the study area, leading was environmental issues $39 \%$, followed by human health $19.5 \%$, pollution of lake $16 \%$, water $10 \%$, chemicals in lake $6 \%$, cultural issues $4 \%$. Employed respondent were aware of many types of researches going on within the study area. This can be attributed to their working environment such as flower industry, tourism, government, and schools. Self employed respondents mentioned the researches which they were aware done as follow; water $34 \%$, human health $34 \%$, environmental issues $22 \%$ and pollution of Lake $11 \%$ (Figure 5). Most of the respondents connected research activities in Naivasha with their socioeconomic activities. In other words, they probably viewed research as an opportunity to offer solutions to some of the problems affecting them; for instance, the fishing communities were keener on clean water and reduced deaths of fish to improve their livelihood. The pastoralists were more concerned with the health of pasture and water for livestock and hence reduced death of animals, and that means more income to them. 


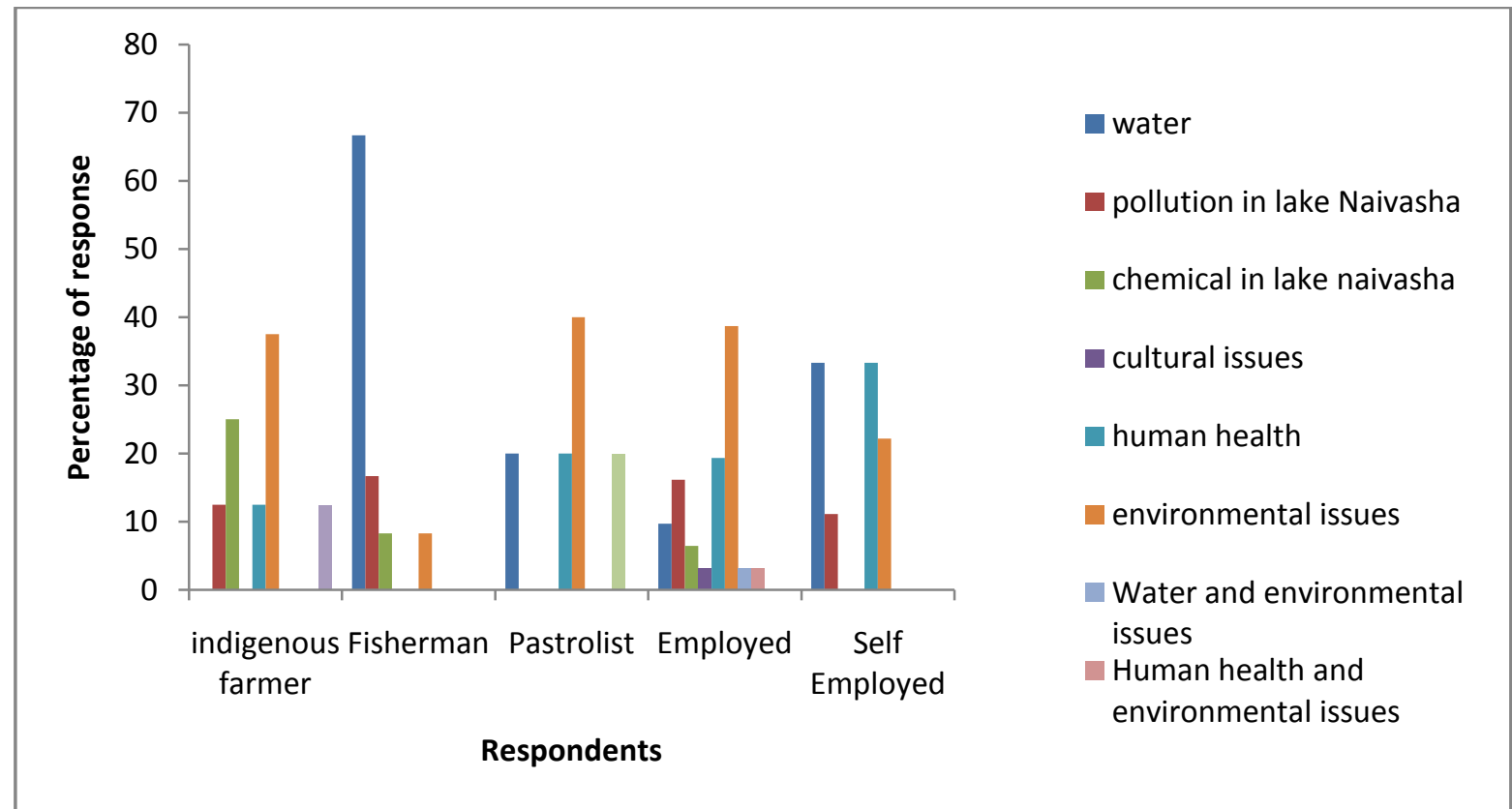

Figure 5: Issues addressed by various Researches within LNB

In response to the question on whether the respondents had access to ecosystem health research information, the study found that most of the sampled respondents had no access to ecosystem health research information. This was evidenced by the fact that $80 \%$ of the pastoralists had no access to the information. The study also found that $70 \%$ of the fishermen, $64 \%$ of the indigenous farmers, $60 \%$ of the self employed and $58 \%$ of the employed had no access to ecosystem health research information. This can be attributed to their level of education which is probably low. Among the employed the findings can be attributed to the probability that most of them are either primary school leavers or secondary school leavers who understand what is going on around the environment and hence they had some access to ecosystem health research information (Figure 6). This demonstrates probably that either the people did not know where to get the information or they did not know how to go about the process of getting the research information which can help solve some of the environmental problems.

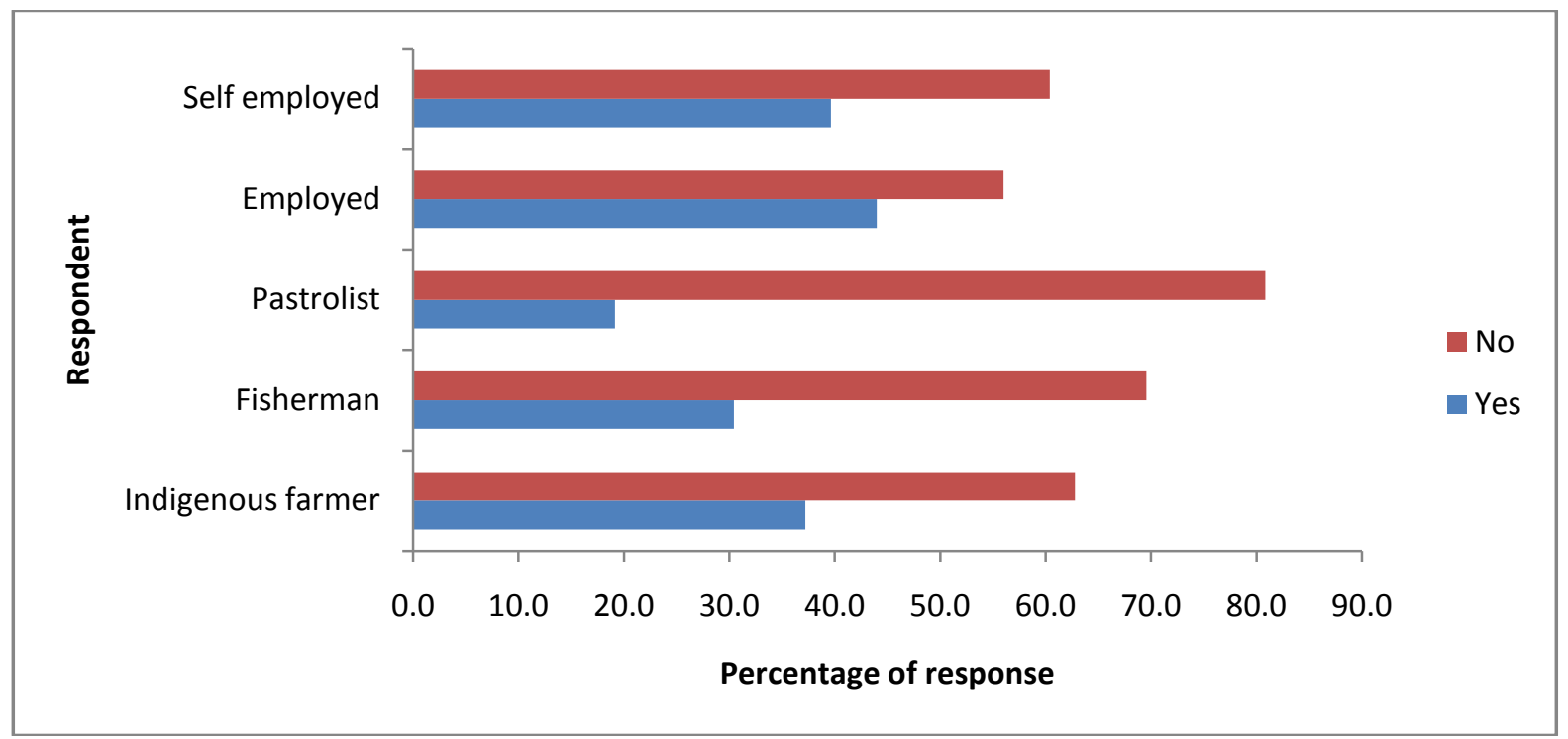

Figure 6: Access of Research Information by Respondents

In view of the observation that most of the respondents had limited access to ecosystem health research information, it was curious to find out the information base upon which they used to contribute to environmental resources conservation. The study found that the major source of the information for the respondents was the radio. This was indicated by $51 \%$ of the farmers, $61 \%$ of the fishermen, $50 \%$ of the pastoralists, $64 \%$ of the 
employed and $75 \%$ of the self employed. These findings are probably attributable to the fact that radio is cheap and can be afforded by most households. The study also found that television was a source of ecosystem health research finding as indicated by $26 \%$ of the farmers, $18 \%$ of the fishermen, $23 \%$ of the pastoralist, $27 \%$ of the employed, and $33 \%$ of the self employed. As may be observed, these percentages are much lower compared to those attributed to radio because television sets are more expensive, thus reducing their accessibility as source of information.

The study further found that some of the respondents accessed research information from printed media as indicated by $5 \%$ of the fishermen, $2 \%$ of the pastoralists, $15 \%$ of the employed and $8 \%$ of the self employed. This was probably low due to the fact that the cost of printed media is expensive to most respondents and also low levels of education prevent a significant number of respondents from using it. Use of internet to access ecosystem health research information was even lower as indicated by $0 \%$ of the farmers, $9 \%$ of the fishermen, $0 \%$ of the pastoralists, $15 \%$ of the employed and $0 \%$ self employed. Again this can be attributed to low levels of education of the respondents. In addition, the cost of using internet may be high to most respondents, as well as the limited or lack of computer skills. Access to ecosystem health research information from research institutions is low as indicated by $11 \%$ of the farmers, $0 \%$ of the fishermen, $6 \%$ of the pastoralists, $11 \%$ of the employed and $11 \%$ of the self employed. This is probably due to lack of awareness that research institutions have ecosystem health research information needed by respondents. The study also indicated that access to ecosystem health research information from Baraza was also very low as indicated by $4 \%$ of the farmers, $4 \%$ of the fishermen, $19 \%$ of the pastoralists, $2 \%$ of the employed, and $3 \%$ of the self employed. The low usage of Baraza can be attributed to lack of awareness by the respondents of the importance of Baraza, or probably most respondents have not be sensitized why Baraza are important (Figure 7).

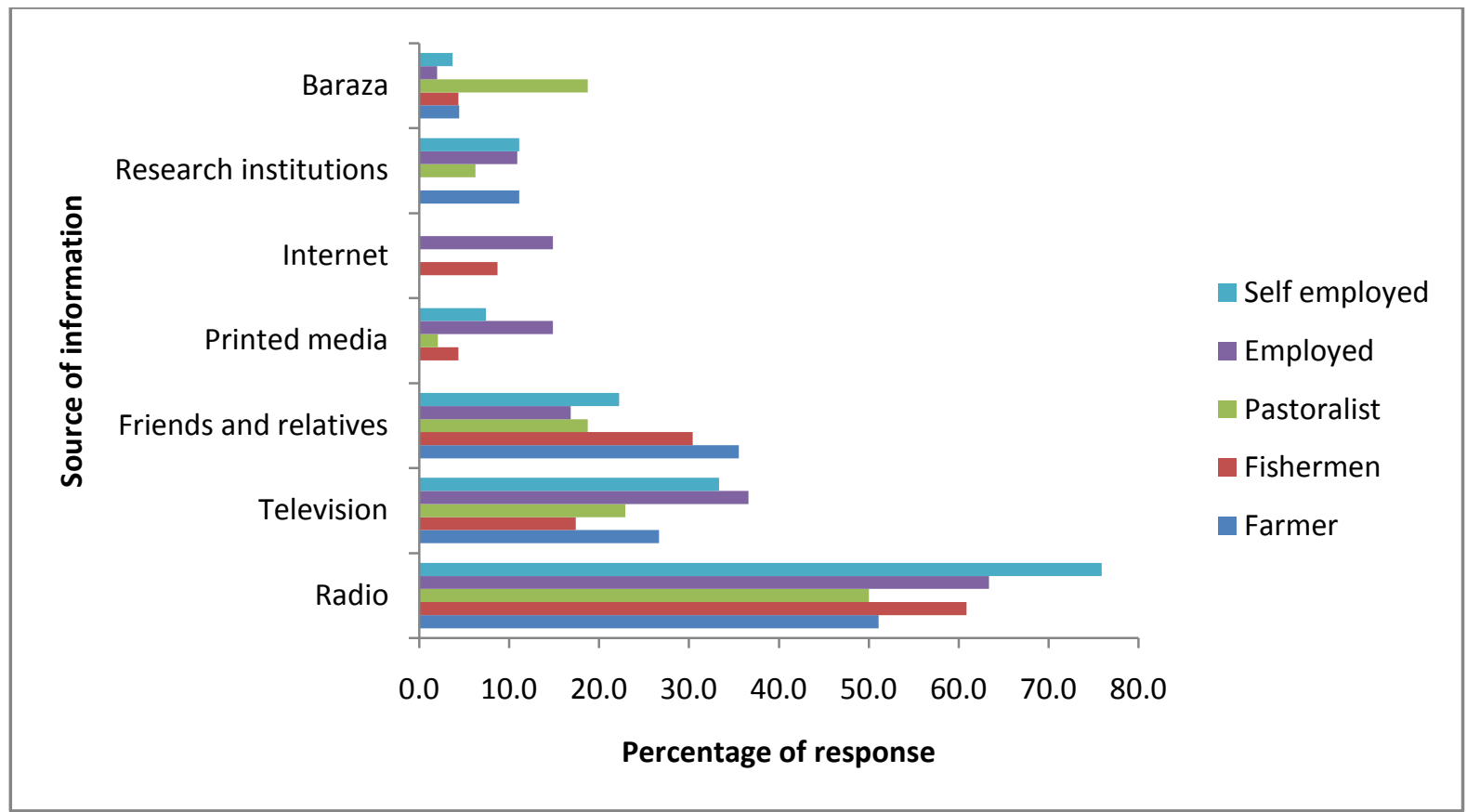

Figure 7: Sources of Research Information by Respondents

Besides establishing the importance of research information, respondents were also asked to indicate the most important research information they were interested in. The study found that $65 \%$ of the fishermen indicated that the most important information for them was that which focuses on the concentration and type of pollutants entering Lake Naivasha, followed by human health $26 \%$, watershed hydrology $4 \%$, ecosystem health $4 \%$ and management of solid waste $4 \%$. Since the livelihood of fishermen is hinged upon the Lakes resources, that probably explains why they are concerned about pollutants entering the lake and how these in turn affect human health. The study also found that the importance of research information for farmers was in relation to ecosystem health $28 \%$, followed by concentration and type of pollutants in the Lake Naivasha $22 \%$, human health $20 \%$, watershed hydrology $18 \%$ and management of solid waste $11 \%$. Among the pastoralists, the important research information was found to be related to concentration and type of pollutants in Lake Naivasha $32 \%$, followed by watershed hydrology $29 \%$, ecosystem health $23 \%$, human health $14 \%$ and management of solid waste $10 \%$. The study found that among the employed and the self employed interviewees, watershed hydrology information was considered important as indicated by $29 \%$ and $30 \%$ respectively. From the findings of the study, it can be observed that all the respondents value ecosystem health research information generated. 
However, the degree of importance varies with the occupation and the associated socioeconomic activities of the respondents (Figure 8).

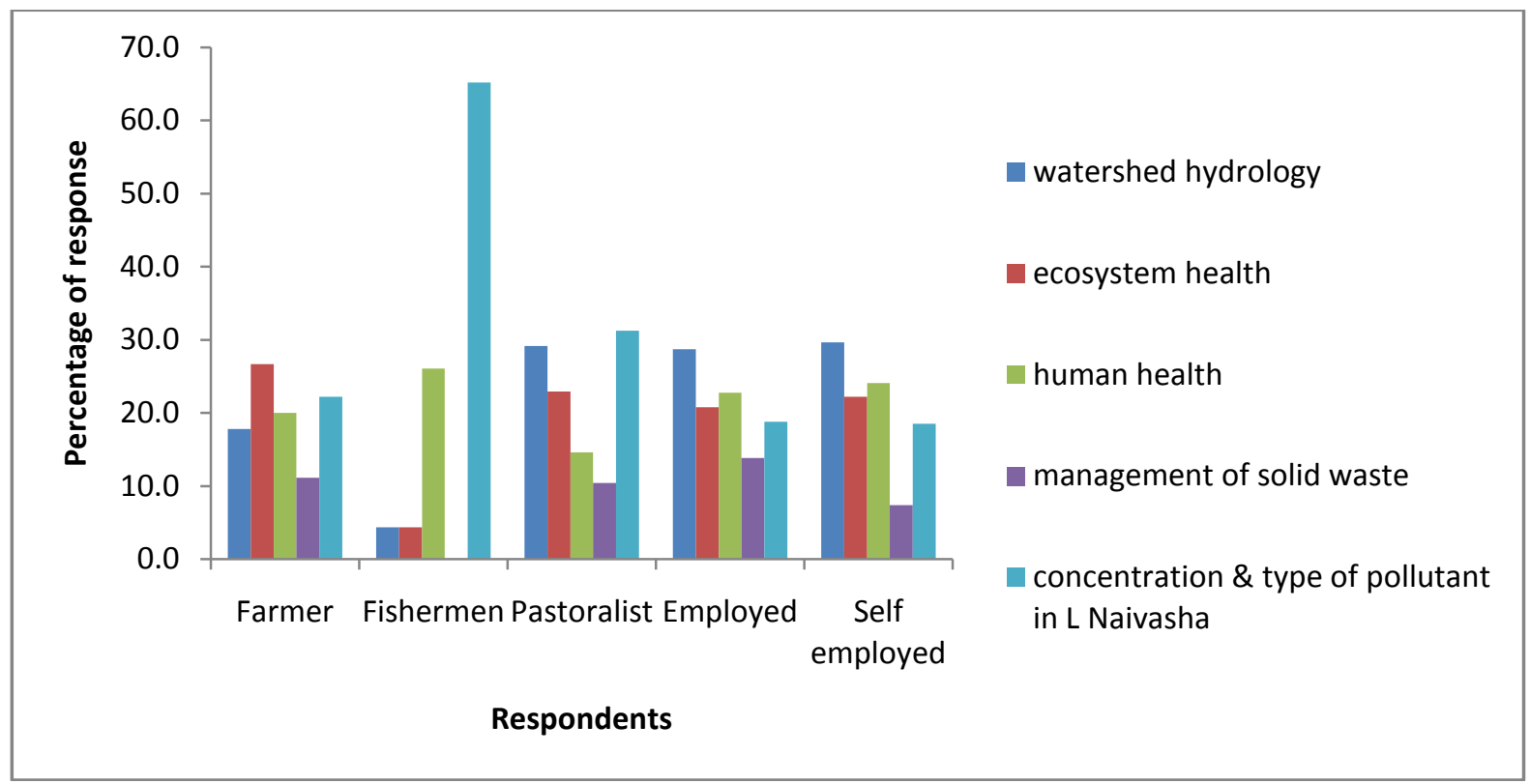

Figure 8: Most important Research Information Required by Respondents

The findings of the study clearly show that people who live around Lake Naivasha need ecosystem health research information on various issues based on their socio-economic activities. Problems influencing access to ecosystem health research information include; lack of a resource centre, cost of accessibility, level of education, use of technical language, lack of interest, lack of resource personnel, and lastly, lack of proper translation of research information.

The level of education of the respondents contributed to problem of accessibility to ecosystem health research information (Figure 9). Since most of the respondents had no access to ecosystem health research information, this explains probably why they were not able to tell whether the language used was technical, hence the low percentage response. On the other hand, most respondents were probably not interested in accessing ecosystem health research findings as demonstrated by low response. The lack of resource centre comes out very strongly as a problem in accessing research information. Most respondents expressed a desire for a place they could visit and access the ecosystem health research information they needed. Given the fact that there is no such resource centre within the study area, the respondents probably could not tell whether the ecosystem health research information generated needed coordination and management.

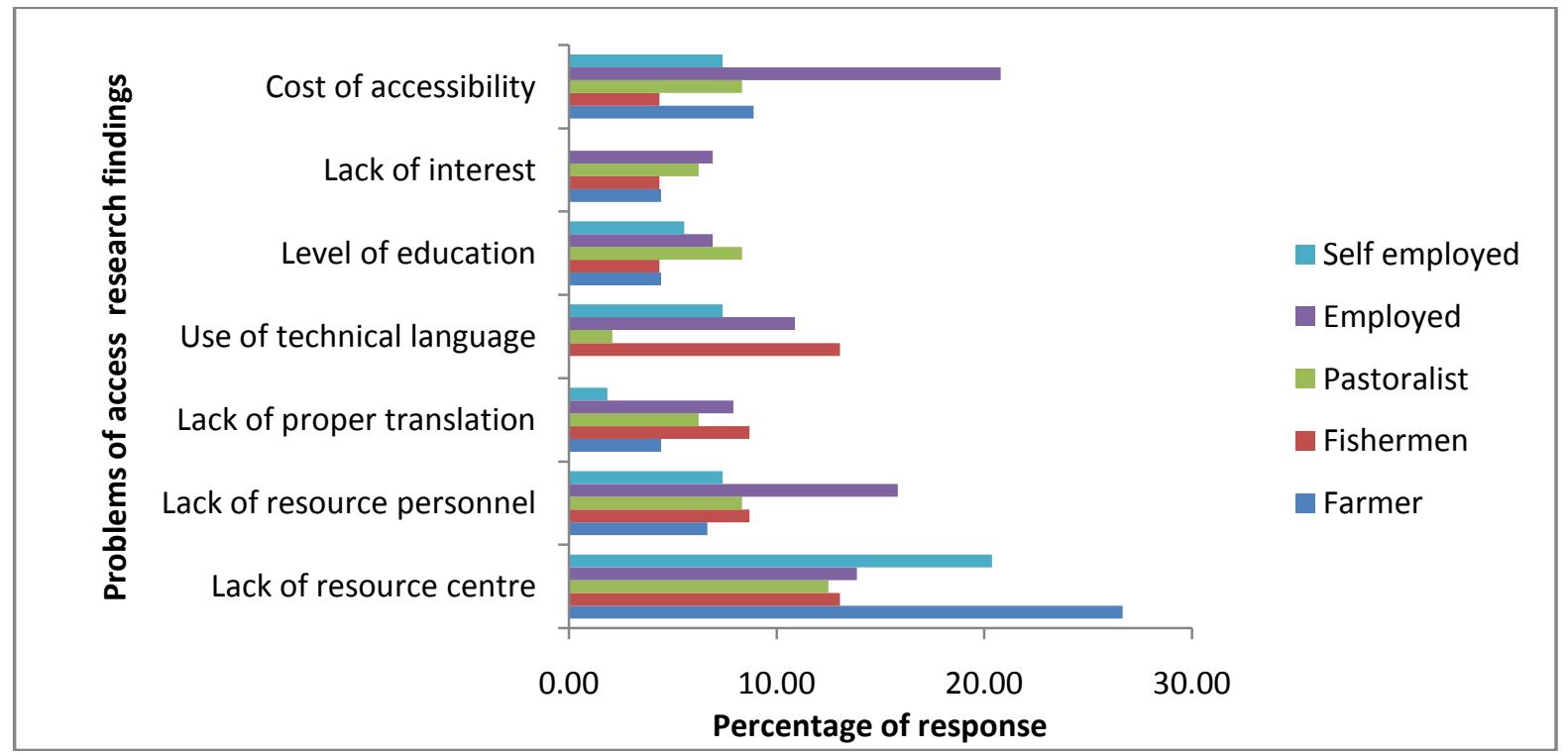

Figure 9: Problems in Accessing Research Information by Respondents 
Related to accessibility of ecosystem health research information was awareness. The major factor limiting access to ecosystem health research information was lack of awareness on the existence of ecosystem health research information as indicated by $65 \%$ of the farmers, $50 \%$ of the self employed, $42 \%$ of the fishermen, $42 \%$ of the employed and $40 \%$ of the pastoralists. Another factor which limited the accessibility of ecosystem health research findings was lack of education as indicated by $30 \%$ of the farmers, $56 \%$ of the fishermen, $40 \%$ of the pastoralist, $40 \%$ of the employed and $25 \%$ of the self employed (Figure 10).

These research findings closely concur with the those of a study done by (Michael et al., 2007), in which he found that the factors influencing the utilization of research findings by all stakeholders include access to information, relevance of the research, use of the research perceived as a time consuming process, trust in the research, authority of those who present their views, competency in research methods, and priority of research in policy process and accountability. This also concurs closely with a study done by (Thomas, 2010) in which the reasons for failure of research finding to translate into utilization include historical, social, economic, cultural, organizational factors slow or impede the transfer, high cost, intensive time demanded, high level of staff expertise required, difficulty to learn or understand, not developed to suit the users need, not designed to be self sustaining and highly specific to a particular setting.

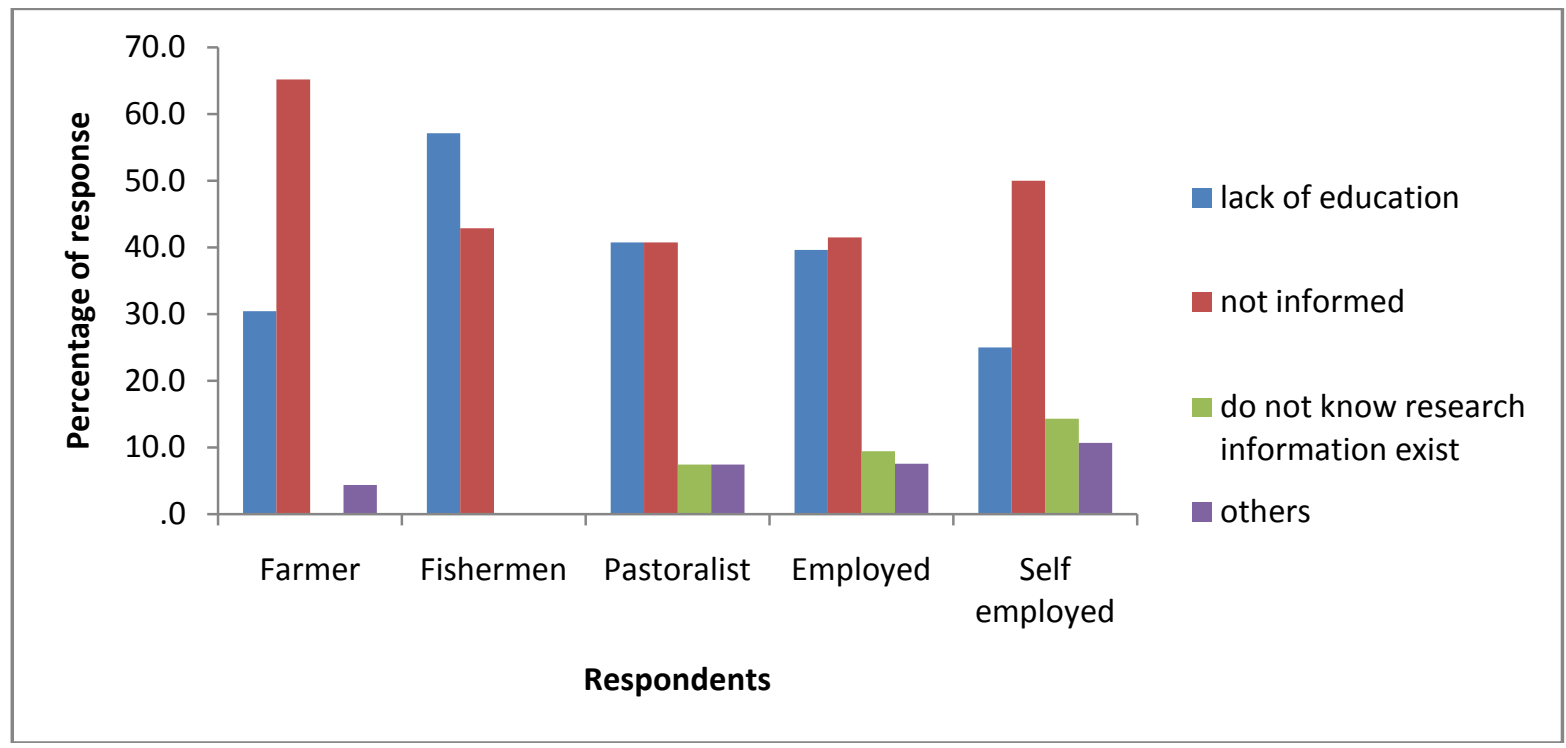

Figure 10: Problems that Limit Accessing Research Information by Respondents

To determine a relationship between awareness, accessibility and usefulness of ecosystem health research information to respondents with education, the variable were subjected to a cross tabulation. This was to establish if there is a relationship between awareness of research finding information and education level, usefulness of research findings and education level and accessibility of research findings and education level.

\begin{tabular}{|c|c|c|c|c|c|}
\hline & & \multicolumn{4}{|c|}{$\begin{array}{l}\text { Is respondent aware of research } \\
\text { activities }\end{array}$} \\
\hline & & Aware & & Not aware & Total \\
\hline \multirow[t]{2}{*}{ No formal education } & Count & 4 & & 43 & 47 \\
\hline & $\begin{array}{l}\% \text { within Highest } \\
\text { level of education }\end{array}$ & $8.5 \%$ & & $91.5 \%$ & $100.0 \%$ \\
\hline \multirow[t]{2}{*}{ Primary } & Count & 16 & & 73 & 89 \\
\hline & $\begin{array}{l}\% \text { within Highest } \\
\text { level of education }\end{array}$ & $18.0 \%$ & & $82.0 \%$ & $100.0 \%$ \\
\hline \multirow[t]{2}{*}{ Secondary } & Count & 41 & & 62 & 103 \\
\hline & $\begin{array}{l}\% \text { within Highest } \\
\text { level of education }\end{array}$ & $39.8 \%$ & & $60.2 \%$ & $100.0 \%$ \\
\hline \multirow[t]{2}{*}{ College } & Count & 16 & $=$ & 9 & 25 \\
\hline & $\begin{array}{l}\% \text { within Highest } \\
\text { level of education }\end{array}$ & $64.0 \%$ & & $36.0 \%$ & $100.0 \%$ \\
\hline \multirow[t]{2}{*}{ University } & Count & 1 & & 0 & 1 \\
\hline & $\begin{array}{l}\% \text { within Highest } \\
\text { level of education }\end{array}$ & $100.0 \%$ & & $.0 \%$ & $100.0 \%$ \\
\hline \multirow[t]{2}{*}{ Total } & Count & 78 & $\sqrt{ }$ & 187 & 265 \\
\hline & $\begin{array}{l}\% \text { within Highest } \\
\text { level of education }\end{array}$ & $29.4 \%$ & & $70.6 \%$ & $100.0 \%$ \\
\hline
\end{tabular}




\section{Chi-Square test}

\begin{tabular}{|l|l|l|l|}
\hline & $x^{2}$ & $\mathrm{df}$ & $\mathrm{P}$ \\
\hline Pearson Chi-Square & $37.644^{\mathrm{a}}$ & 4 & .000 \\
\hline Likelihood Ratio & 38.820 & 4 & .000 \\
\hline Linear-by-Linear Association & 35.684 & 1 & .000 \\
\hline N of Valid Cases & 265 & & \\
\hline
\end{tabular}

At $95 \%$ confidence interval the relationship between education and awareness of research activities is statistically significant $(\mathrm{p})<0.05\left(x^{2}=37.644, \mathrm{p}=0.00, \mathrm{df}=4\right)$. This suggests that there is a strong relationship between level of education and awareness to research activities. It is evident that level of awareness increases with increase in the level of education (Table 1). This is attributed to the fact that people's awareness of the importance of ecosystem health research activities is related to exposure which in turn is facilitated by their level of education.

Table 2: Cross Tabulation of Level of Education and Usefulness of Research Information

\begin{tabular}{|c|c|c|c|c|c|c|c|}
\hline & & $\begin{array}{l}\text { least } \\
\text { useful }\end{array}$ & usefulness & $\begin{array}{l}\text { of research } \\
\text { averagely } \\
\text { useful }\end{array}$ & $\begin{array}{l}\text { formation } \\
\text { above } \\
\text { average } \\
\text { useful }\end{array}$ & $\begin{array}{l}\text { very } \\
\text { useful }\end{array}$ & Total \\
\hline \multirow{2}{*}{$\begin{array}{l}\text { No formal } \\
\text { education }\end{array}$} & Count & 6 & 13 & 2 & 12 & 5 & 38 \\
\hline & $\begin{array}{l}\% \quad \text { within } \\
\text { Highest level } \\
\text { of education }\end{array}$ & $15.8 \%$ & $\begin{array}{l}34.2 \% \\
\text { increase }\end{array}$ & $\begin{array}{r}5.3 \% \\
\text { decreas }\end{array}$ & $31.6 \%$ & $13.2 \%$ & $100.0 \%$ \\
\hline \multirow[t]{2}{*}{ Primary } & Count & 16 & 19 & 8 & 32 & 15 & 90 \\
\hline & $\begin{array}{l}\% \quad \text { within } \\
\text { Highest level } \\
\text { of education }\end{array}$ & $17.8 \%$ & $\begin{array}{c}21.1 \% \\
\text { increase }\end{array}$ & $\begin{array}{c}8.9 \% \\
\text { lo decreas }\end{array}$ & $35.6 \%$ & $16.7 \%$ & $100.0 \%$ \\
\hline \multirow[t]{2}{*}{ Secondary } & Count & 15 & 10 & 7 & 39 & 27 & 98 \\
\hline & $\begin{array}{l}\% \quad \text { within } \\
\text { Highest level } \\
\text { of education }\end{array}$ & $15.3 \%$ & $\begin{array}{c}10.2 \% \\
\text { o increase }\end{array}$ & $\begin{array}{c}7.1 \% \\
\text { no decrea }\end{array}$ & $39.8 \%$ & $27.6 \%$ & $100.0 \%$ \\
\hline \multirow[t]{3}{*}{ College } & Count & 1 & 2 & 5 & 13 & 4 & 25 \\
\hline & $\% \quad$ within & $4.0 \%$ & $8.0 \%$ & $20.0 \%$ & $52.0 \%$ & $16.0 \%$ & $100.0 \%$ \\
\hline & $\begin{array}{l}\text { Highest level } \\
\text { of education }\end{array}$ & & light incre & & 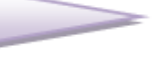 & & \\
\hline \multirow[t]{2}{*}{ University } & Count & 0 & 0 & 0 & 0 & 1 & 1 \\
\hline & $\begin{array}{l}\% \quad \text { within } \\
\text { Highest level }\end{array}$ & $.0 \%$ & crease & $.0 \%$ & $.0 \%$ & $100.0 \%$ & $100.0 \%$ \\
\hline \multirow[t]{2}{*}{ Total } & $\begin{array}{l}\text { of education } \\
\text { Count }\end{array}$ & 38 & 44 & 22 & 96 & 52 & 252 \\
\hline & $\begin{array}{l}\% \text { within } \\
\text { Highest level } \\
\text { of education }\end{array}$ & $15.1 \%$ & $17.5 \%$ & $8.7 \%$ & $38.1 \%$ & $20.6 \%$ & $100.0 \%$ \\
\hline
\end{tabular}

Chi-Square Tests

\begin{tabular}{lrrr} 
& \multicolumn{1}{c}{$\mathrm{K}^{2}$} & $\mathrm{df}$ & $\mathrm{P}$ \\
\hline Pearson Chi-Square & $27.975^{\mathrm{a}}$ & 16 & .032 \\
Likelihood Ratio & 26.598 & 16 & .046 \\
Linear-by-Linear & 9.839 & 1 & .002 \\
Association & & & \\
N of Valid Cases & 252 & & \\
\hline
\end{tabular}

The relationship between level of education and usefulness of ecosystem health research information at $95 \%$ confidence interval was statistically significant $(\mathrm{p})<0.05\left(x^{2}=27.975, \mathrm{df}=16, \mathrm{p}=0.032\right)$. From the cross tabulation (Table 2) it is observed that a strong relationship between the level of education and usefulness of ecosystem health research information exists. Such usefulness increases with increase in level of education. 
Table 3: Cross Tabulation of Level of Education and Access to Research Information

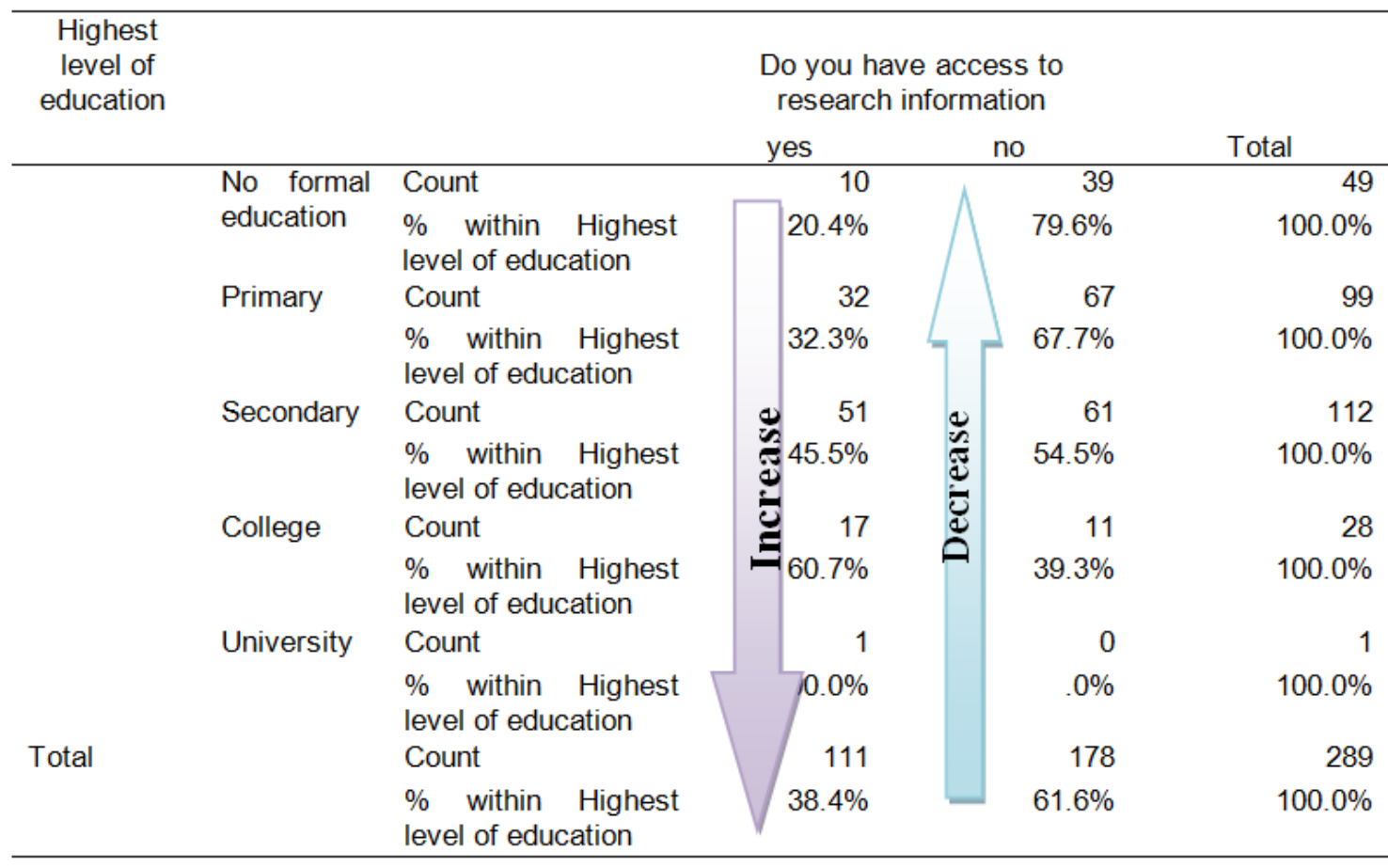

Chi-Square Tests

\begin{tabular}{cccc} 
& $\mathcal{x}^{2}$ & $\mathrm{df}$ & $\mathrm{P}$ \\
\hline Pearson Chi- & $18.159^{\mathrm{a}}$ & 4 & .001 \\
Square & & & .001 \\
Likelihood Ratio & 18.886 & 4 & .000 \\
Linear-by-Linear & 17.724 & 1 & \\
Association & & & \\
N of Valid Cases & 289 & & \\
\hline
\end{tabular}

The relationship between level of education and access to ecosystem health research information is statistically significant $(\mathrm{p})<0.05\left(\mathcal{x}^{2}=18.159, \mathrm{df}=4, \mathrm{p}=0.001\right)$. From the results it confirms there is a strong relationship between level of education and access to ecosystem health research information (Table 3 ). This is attributed to the fact that the higher the level of education one has, the more access to research information one is likely to have, know the importance and how to access it.

Table 4: Cross Tabulation of Age group and Awareness of Research activities

\begin{tabular}{|c|c|c|c|c|c|}
\hline & & & $\begin{array}{l}\text { Is respc } \\
\text { rese }\end{array}$ & $\begin{array}{l}\text { dent aware of } \\
\text { h activities }\end{array}$ & \\
\hline & & & Aware & Not aware & Total \\
\hline \multirow[t]{14}{*}{ Age group } & $18-24$ & Count & 13 & 50 & 63 \\
\hline & & $\%$ within Age & $20.6 \%$ & $79.4 \%$ & $100.0 \%$ \\
\hline & $25-34$ & Count & 45 & 81 & 126 \\
\hline & & $\underset{\text { group }}{\% \text { within Age }}$ & $35.7 \%$ & $64.3 \%$ & $100.0 \%$ \\
\hline & $35-44$ & Count & 13 & 40 & 53 \\
\hline & & $\begin{array}{c}\% \text { within Age } \\
\text { group }\end{array}$ & $24.5 \%$ & $75.5 \%$ & $100.0 \%$ \\
\hline & $45-54$ & Count & 5 & 13 & 18 \\
\hline & & $\%$ within Age & $27.8 \%$ & $72.2 \%$ & $100.0 \%$ \\
\hline & 55 & Count & 1 & 4 & 5 \\
\hline & $\begin{array}{c}\text { and } \\
\text { abov } \\
e\end{array}$ & $\begin{array}{c}\% \text { within Age } \\
\text { group }\end{array}$ & $20.0 \%$ & $80.0 \%$ & $100.0 \%$ \\
\hline & don't & Count & 1 & 0 & 1 \\
\hline & know & $\begin{array}{c}\% \text { within Age } \\
\text { group }\end{array}$ & $100.0 \%$ & $.0 \%$ & $100.0 \%$ \\
\hline & & Count & 78 & 188 & 266 \\
\hline & & $\begin{array}{c}\% \text { within Age } \\
\text { group }\end{array}$ & $29.3 \%$ & $70.7 \%$ & $100.0 \%$ \\
\hline
\end{tabular}


Chi-Square Tests

\begin{tabular}{llll} 
& $x^{2}$ & df & P \\
\hline Pearson Chi-Square & $8.007^{\mathrm{a}}$ & 5 & .156 \\
Likelihood Ratio & 8.158 & 5 & .148 \\
Linear-by-Linear & .288 & 1 & .591 \\
Association & & & \\
N of Valid Cases & 266 & & \\
\hline
\end{tabular}

The relationship between age group and awareness of research activities at 95\% confidence interval was statistically insignificant $(p)>0.005\left(\varkappa^{2}=8.007, \mathrm{df}=5, \mathrm{p}=0.156\right)$. From the cross tabulation (Table 4) it is observed that there is no relationship between age group and awareness of research activities. This means that awareness of research activities is not influenced by age, rather by how well one is exposed in terms of education level.

Table 5: Cross Tabulation of Age and Usefulness of Research Information.

\begin{tabular}{|c|c|c|c|c|c|c|c|}
\hline & & $\begin{array}{l}\text { rate use } \\
\text { least } \\
\text { useful } \\
\text { [1] }\end{array}$ & $\begin{array}{l}\text { useful [ } 2 \\
\text { to 3] }\end{array}$ & $\begin{array}{l}\text { averagely } \\
\text { useful [4] }\end{array}$ & $\begin{array}{l}\text { on } \\
\text { above } \\
\text { average } \\
\text { useful [5 } \\
\text { to } 6 \text { ] }\end{array}$ & $\begin{array}{l}\text { very } \\
\text { useful } \\
{[7]}\end{array}$ & Total \\
\hline \multirow[t]{3}{*}{$18-24$} & \multirow{3}{*}{$\begin{array}{l}\text { Count } \\
\% \quad \text { within } \\
\text { Age group }\end{array}$} & 4 & 8 & 2 & 24 & 20 & 58 \\
\hline & & $6.9 \%$ & $13.8 \%$ & $3.4 \%$ & $41.4 \%$ & $34.5 \%$ & $100.0 \%$ \\
\hline & & \multicolumn{6}{|c|}{ No increase no decrease } \\
\hline \multirow[t]{2}{*}{$25-34$} & Count & 20 & 19 & 11 & 47 & 22 & 119 \\
\hline & $\begin{array}{l}\% \quad \text { within } \\
\text { Age group }\end{array}$ & $16.8 \%$ & $16.0 \%$ & $9.2 \%$ & $39.5 \%$ & $18.5 \%$ & $100.0 \%$ \\
\hline \multirow[t]{3}{*}{$35-44$} & Count & 10 & 10 & 6 & 22 & 6 & 54 \\
\hline & $\%$ within & $18.5 \%$ & $18.5 \%$ & $11.1 \%$ & $40.7 \%$ & $11.1 \%$ & $100.0 \%$ \\
\hline & Age group & \multicolumn{6}{|c|}{ No increase no decrease } \\
\hline \multirow[t]{2}{*}{$45-54$} & Count & 3 & 6 & 2 & 4 & 1 & 16 \\
\hline & $\begin{array}{l}\% \quad \text { within } \\
\text { Age group }\end{array}$ & $18.8 \%$ & $37.5 \%$ & $12.5 \%$ & $25.0 \%$ & $6.3 \%$ & $100.0 \%$ \\
\hline \multirow{2}{*}{$\begin{array}{ll}55 & \text { and } \\
\text { above } & \end{array}$} & Count & 2 & 1 & 1 & 0 & 2 & 6 \\
\hline & $\begin{array}{l}\% \text { within } \\
\text { Age group }\end{array}$ & $33.3 \%$ & $16.7 \%$ & $16.7 \%$ & $.0 \%$ & $33.3 \%$ & $100.0 \%$ \\
\hline \multirow[t]{2}{*}{ don't know } & Count & 0 & 0 & 0 & 0 & 1 & 1 \\
\hline & $\begin{array}{l}\% \quad \text { within } \\
\text { Age group }\end{array}$ & $.0 \%$ & $.0 \%$ & $.0 \%$ & $.0 \%$ & $100.0 \%$ & $100.0 \%$ \\
\hline \multirow[t]{2}{*}{ Total } & Count & 39 & 44 & 22 & 97 & 52 & 254 \\
\hline & $\begin{array}{l}\% \text { within } \\
\text { Age group }\end{array}$ & $15.4 \%$ & $17.3 \%$ & $8.7 \%$ & $38.2 \%$ & $20.5 \%$ & $100.0 \%$ \\
\hline
\end{tabular}

Chi-Square Tests

\begin{tabular}{lllll}
\multicolumn{1}{c}{$x^{2}$} & df & P & \\
\hline Pearson Chi- & 29.279 & 20 & .082 \\
Square & & & .058 \\
Likelihood Ratio & 30.807 & 20 & .002 \\
Linear-by-Linear & 9.876 & 1 & \\
Association & & & \\
N of Valid Cases & 254 & &
\end{tabular}


This study was also keen to establish the relationship between age group and usefulness of research information (Table 5). And as the statistical analysis shows, there is no significant relationship between the two variable i.e. age group and usefulness of research findings $p>0.005\left(x^{2}=29.279, \mathrm{df}=20, \mathrm{P}=0.082\right)$. Usefulness of research information is probably attributed to the level of education and exposure but not the age.

Table 6: Cross Tabulation of Age group and Access to Research Information

\begin{tabular}{|c|c|c|c|c|c|c|}
\hline & & & & \multicolumn{2}{|c|}{$\begin{array}{c}\text { Do you have access } \\
\text { to research } \\
\text { information above }\end{array}$} & \multirow[b]{2}{*}{ Total } \\
\hline & & & & $\frac{\text { yes }}{34}$ & no & \\
\hline \multirow[t]{12}{*}{ Age group } & $18-24$ & \multicolumn{2}{|l|}{ Count } & $A$ & 31 & 65 \\
\hline & & $\begin{array}{l}\% \text { within } \\
\text { group }\end{array}$ & Age & $52.3 \%$ & $47.7 \%$ & $100.0 \%$ \\
\hline & $25-34$ & Count & & - & 85 & 138 \\
\hline & & $\begin{array}{l}\% \text { within } \\
\text { group }\end{array}$ & Age & 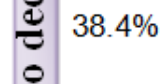 & $61.6 \%$ & $100.0 \%$ \\
\hline & $35-44$ & Count & & E & 44 & 61 \\
\hline & & $\begin{array}{l}\% \quad \text { within } \\
\text { group }\end{array}$ & Age & 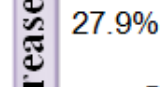 & $72.1 \%$ & $100.0 \%$ \\
\hline & $45-54$ & Count & & $\mathscr{Z}$ & 15 & 20 \\
\hline & & $\begin{array}{l}\% \quad \text { within } \\
\text { group }\end{array}$ & Age & $\begin{array}{l}=25.0 \% \\
7\end{array}$ & $75.0 \%$ & $100.0 \%$ \\
\hline & 55 and above & Count & & 2 & 3 & 5 \\
\hline & & $\begin{array}{l}\% \quad \text { within } \\
\text { group }\end{array}$ & Age & $40.0 \%$ & $60.0 \%$ & $100.0 \%$ \\
\hline & don't know & Count & & 0 & 1 & 1 \\
\hline & & $\begin{array}{l}\% \text { within } \\
\text { group }\end{array}$ & Age & $.0 \%$ & $100.0 \%$ & $100.0 \%$ \\
\hline Total & & Count & & 111 & 179 & 290 \\
\hline & & $\begin{array}{l}\% \quad \text { within } \\
\text { group }\end{array}$ & Age & $38.3 \%$ & $61.7 \%$ & $100.0 \%$ \\
\hline
\end{tabular}

Chi-Square Tests

\begin{tabular}{lclc} 
& \multicolumn{1}{c}{$\mathrm{x}^{2}$} & $\mathrm{df}$ & $\mathrm{P}$ \\
\hline Pearson Chi- & $10.333^{\mathrm{a}}$ & 5 & .066 \\
Square & & & .057 \\
Likelihood Ratio & 10.728 & 5 & .005 \\
Linear-by-Linear & 7.995 & 1 & \\
Association & & & \\
N of Valid Cases & 290 & & \\
\hline
\end{tabular}

Further, it is evident that the relationship between age group and access to research information at $95 \%$ confidence interval was statistically insignificant $(\mathrm{p})>0.05\left(x^{2}=10.333, \mathrm{df}=5, \mathrm{P}=0.066\right)$. The results show that there is no relationship between age group and access to research information (Table 6). This can be attributed to level of education one has and exposure one has but not the age.

\section{Summary of Findings}

Many research initiatives have been undertaken with limited involvement of all the stakeholders in sharing of ecosystem health research findings. In this regard there is need to share the research findings to empower all the stakeholders for sustainable management of Lake Naivasha Basin. Factors contributing to the utilization of ecosystem health research findings include; lack of awareness of the existence of ecosystem health research finding information, lack of resource centre, lack of resource personnel, use of technical language, inadequate education, and inadequate access to research findings among the stakeholders.

\section{Conclusions}

The study concluded that the factors influencing utilization of research findings were lack of awareness, use of technical language and inadequate access to research findings. 


\section{Recommendation}

The success of these efforts will depend largely on establishing a resource centre to facilitate storage and easy access to such information to the researchers and the public. Going hand in hand with establishment of the resource centre, it is recommended that link to the centre are developed to allow for access to research findings from LNB. Some of the possible links could include setting up a web site that contains all relevant and appropriate information that could be accessed by all interested parties. It is finally recommended that researchers should be encouraged to share the information on the findings of their studies and to allow access by other researchers and members of public for better decision making with regard to sustainable management of resources within LNB.

One problem which was realized from the finding of this study was the appropriateness of the language used to disseminate the research findings. It is therefore recommended that the results of research findings on the ecosystem health be summarized in simple information bulletins to encourage and sustain interest of the local people in such information. The study also recommends that a panel of experts consisting of representatives from researchers, LNRA, LNGG, Ministry of Fisheries, water and Naivasha Municipal Council be set up to simplify research findings for ease of uptake and thus more utilization. This can then be produced in the form of flyers, posters and brochures.

\section{References}

[1]. Ayenew,Y. A., Wurziger, M., Tegegne, A., and Zollitsch, W., (2007). Urban and Peri- urban Farming Systems and Utilization of the Natural Resources in the North Ethiopian Highlands, University of Kassel-Witzenhausen and University of Göttingen.

[2]. Francesca, G., Robert, J.B., Kenneth, M. M., Nic. P., Jonathan, G., Elena, T., David, M.H., (2011). A review of allo diversity in Lake Naivasha Kenya: Developing conservation action to protect East Africa lakes from the negative impact of alien species. Biological conservation 144(11): 2585-2596

[3]. Francis, M., (2010). The influence of geographic and morphometric factors on the distribution of water birds species in small high altitudes tropical man made reservoirs, central rift valley Kenya. Africa journal of ecology.48(3):676-690.

[4]. Gitahi, S.M., Harper, D.M., Muchiri, S. M., Tole, P.M., Ng'anga, R.M., (2002). "Organochlorine and Organophosphorus pesticide concentration in water, sediments, and selected organisms in Lake Naivasha (Kenya).” Hydrobiologia 488 (1-3):123-128

[5]. HCDA., (2007). Horticultural Crop Development Authority report. Government Printing press Kenya

[6]. Michael, A. A., Atle, F., Diadie, M., (2007). Factors influencing the utilization of Research finding by Health Policy makers in developing country: the selection of Mali's Essential Medicine 10: 1186/1478-4505

[7]. Mireri, C., (2005). Challenges facing the conservation of Lake Naivasha Kenya, Kenyatta University Printing Press Nairobi Kenya.

[8]. Robert, B., Eric, O.O., Sarah, H., (2006). Lake Naivasha Experience and Lesson Learned Briefs. Lake Naivasha Riparian Association.

[9]. Thomas, W.E., (2010). Knowledge dissemination and adoption. Journal of Allied Health Washington Vol. 39.Iss 2; Pg 63, 1Pgs 